\title{
Esophageal Involvement and Gastroesophageal Reflux Disease in Systemic Sclerosis: A Tertiary Center Experience
}

\section{Sistemik Skleroz'da Özofagus Tutulumu ve Gastroözofageal Reflü Hastalığı: Üçüncü Basamak Deneyimi}

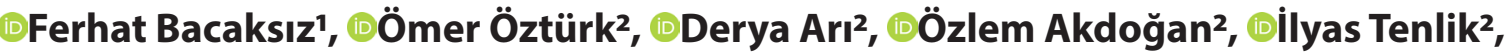

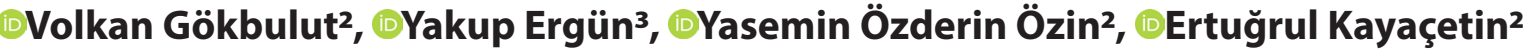 \\ 'Gazi Yaşargil Training and Research Hospital, Department of Gastroenterology, Diyarbakır, Turkey \\ 2Ministry of Health Ankara City Hospital, Clinic of Gastroenterology, Ankara, Turkey \\ ${ }^{3}$ Batman Training and Research Hospital, Department of Medical Oncology, Batman, Turkey
}

\begin{abstract}
Aim: In this study, we investigated the demographic features, endoscopic, manometric, and 24-hour $\mathrm{pH}$ monitoring findings of patients with SS.

Materials and Method:Twenty-six patients with SS who presented with dysphagia or heartburn complaints were identified. Patients' files, endoscopic, manometric, and 24-hour ph monitoring findings of the esophagus were examined.

Results: All of the patients were symptomatic. The average age of 26 patients was 47.9 years and $96 \%$ were women. $46.1 \%$ of them applied with the complaint of heartburn and $53.9 \%$ with the complaint of dysphagia. The frequency of esophagitis in patients with SS was found to be significantly higher $(p=0.005)$. Pathological reflux was detected in $90 \%$ of the patients with SS who underwent 24-hour pH monitoring and it was significantly higher $(\mathrm{p}=0.013)$. The mean esophageal body resting pressure in the patient with SS group was $-0.73 \mathrm{mmHg}$ and was significantly lower than that of control group $(p<0.001)$. The mean resting LES pressure in the patient with SS group was $3.3 \mathrm{mmHg}$ and was significantly lower than that of control group ( $p=0.028$ ).

Conclusion: Esophageal involvement is a hallmark manifestation of SS and typically occurs secondary to heartburn and dysphagia. In our society, the incidence of Gastroesophageal Reflux Disease (GERD) and GERD-related complications is high in SS patients with esophageal symptoms. It is important to refer these patients to experienced gastroenterology centers to be evaluated by endoscopic and then other diagnostic methods.
\end{abstract}

Keywords: Esophageal motility disorder, gastroesophageal reflux disease, systemic sclerosis.
Öz

Amaç: Bu çalışmamızda Sistemik Skleroz (SS) tanılı hastaların demografik özelliklerini, endoskopik, manometrik ve 24 saatlik ph monitorizasyonu bulgularını araştırdık.

Gereç ve Yöntem: Disfaji veya heartburn şikayetleri ile başvurmuş olan 26 SS tanılı hasta tespit edildi. Hastaların, dosyaları, endoskopik, manometrik ve özofagusun 24 saatlik ph monitorizasyonu bulguları incelendi.

Bulgular: SS tanılı hastaların tamamı semptomatikti, 26 Hastanın yaş ortalaması 47,9 idi, \%96'sı kadındı. \%46,1 'i heartburn şikayetiyle, $\% 53,9^{\prime}$ u disfaji şikayetiyle başvurmuştu. SS tanılı hastalarda özofajit sıkığı anlamlı ölçüde yüksek saptandı $(p=0,005)$. SS tanılı hastalarda, 24 saatlik ph monitorizasyonu yapılan hastaların \%90'ında patolojik reflü tespit edilmişti ve anlamlı derecede yüksekti $(p=0,013)$. SS tanılı hastaların ortalama Özofagus Gövde Dinlenim Basıncı -0,73 mmHg olup kontrol grubuna göre anlamlı olarak düşüktü $(p<0,001)$. SS tanılı hastaların ortalama LES Dinlenim Basınc 3,3 mmHg olup anlamlı derecede düşüktü $(p=0,028)$.

Sonuç: Özofageal tutulum SS' nin karakteristik tutulumlarından biridir. Özofagus tutulumu, heartburn ve disfaji gibi şikayetler ile kendini gösterir. Toplumumuzda, özofagus semptomları olan SS hastalarında Gastroözofageal Reflü Hastalığı (GÖRH) ve GÖRH ile ilişkili komplikasyonların görülme sıklığı yüksektir. Bu hastaların endoskopi ve diğer tanı yöntemleriyle değerlendirilmesi için deneyimli gastroenteroloji merkezlerine yönlendirilmesi önem arz etmektedir.

Anahtar Kelimeler: Gastroözofageal reflü hastalığı, özofagus motilite bozuklukları, sistemik skleroz

Corresponding (IIletişim): Ferhat Bacaksız, Gazi Yaşargil Training and Research Hospital, Department of Gastroenterology, Diyarbakır, Turkey E-mail (E-posta): ferhatbcksz@gmail.com

Received (Geliş Tarihi): 06.01.2021 Accepted (Kabul Tarihi): 26.05.2021 


\section{INTRODUCTION}

Systemic Sclerosis (SS) is a rare multisystemic disease of an unclear etiology, characterized by microvascular damage and excessive collagen synthesis and deposition in the skin and visceral organs. ${ }^{[1]}$ The gastrointestinal tract $(\mathrm{Gl})$ is affected in almost $90 \%$ of the patients with SS and the disease may also involve any part of the $\mathrm{Gl}$, from the oral aperture to the rectum. [2] Esophageal motility disorder (EMD), lower esophageal sphincter (LES) incompetence, and the accompanying gastroparesis in some patients are considered as the primary causes of increased frequency of acid reflux. Additionally, dysphagia and gastroesophageal reflux disease (GERD) are commonly seen serious comorbidities in patients with SS. ${ }^{[3]}$ GERD may result in numerous complications including esophagitis, peptic stricture, and Barrett's esophagus (BE). ${ }^{[4]}$ Moreover, if left uncontrolled, GERD may form a basis for recurrent aspiration pneumonia, thereby leading to pulmonary fibrosis. ${ }^{[5]}$ GER and dysphagia have been found to be associated with depressive symptoms in patients with SS. ${ }^{[6]}$ In patients with SS, early assessment of esophageal involvement may create awareness of aggressive treatments for GERD. Additionally, administering treatment protocols involving antacid and prokinetic agents and taking simple precautions such as bedhead elevation may prevent longterm complications including recurrent aspirations and lung injury, thereby improving patients' quality of life. ${ }^{[7]}$ The aim of this study was to evaluate the demographic, endoscopic, manometric, and 24-hour esophageal pH test results in SS patients presenting with esophageal symptoms in our society.

\section{MATERIAL AND METHOD}

This study was approved ethically by the local ethics committee (Date: 27.11.2019, Study No: 12) of from Ministry of Health Ankara City Hospital Clinical Research Ethics Committee, Ankara, Turkey. The study retrospectively reviewed the medical records of 1,827 patients that underwent conventional esophageal manometry at Ankara Training and Research Hospital Gastroenterology Department Motility Polyclinic over the period between January 2008 and December 2018. Twenty-six patients diagnosed with SS were included in the study. For each patient, medical records were reviewed for demographic characteristics including age, gender, and body mass index (BMI) and also for clinical characteristics including 24-hour esophageal $\mathrm{pH}$ test results and endoscopic and manometric findings. The patients included in the study had a diagnosis of SS, underwent esophageal manometry, and were aged over 18 years. Patients aged under 18 years and those with no prior manometric evaluation, suspicious signs of other esophageal motility disorders, active cardiovascular, cerebrovascular and psychopathological disorders, morbid obesity, thyroid diseases, malignancies, other rheumatological diseases involving the esophagus, and a history of surgery for reflux, esophagus, and stomach were excluded from the study. Additionally, a control group of 26 age- and gender-matched patients was also included in the study, who were randomly chosen from among patients that presented to the same department with similar complaints and had normal manometry results.

\section{Statistical analysis}

Data were analyzed using SPSS for Windows version 22.0 (IBM SPSS Inc., Armonk, NY, USA). Continuous variables were expressed as mean \pm standard deviation (SD) and categorical variables were expressed as frequencies ( $\mathrm{n}$ ) and percentages (\%). Two groups were compared using Pearson's Chi-square test and Fisher's Exact Test. A p value of $<0.05$ was considered significant.

\section{RESULTS}

The 26 patients in the patient group comprised 25 (96.2\%) women and $1(3.8 \%)$ man with a mean age of 47.9 years. All of these patients were symptomatic and the most common presenting complaint in the patients was dysphagia (53.9\%) followed by heartburn (46.1\%). The mean BMI in the patient group was $24.1 \mathrm{~kg} / \mathrm{m}^{2}$ and was significantly lower than that of control group ( $p=0.017$ ). Table 1 presents the demographic characteristics of the patients in both groups.

\begin{tabular}{|c|c|c|c|}
\hline & $\begin{array}{c}\text { SS group } \\
(n=26)\end{array}$ & $\begin{array}{c}\text { Control group } \\
(n=26)\end{array}$ & $\mathbf{p}$ \\
\hline $\begin{array}{l}\text { Mean age ( } \pm \text { SD) } \\
\text { (years) }\end{array}$ & $47.9 \pm 1.43$ & $48.4 \pm 1.53$ & 0.90 \\
\hline Female $\mathrm{n}(\%)$ & 25 (96.1\%) & 25 (96.1\%) & 0.75 \\
\hline $\begin{array}{l}\text { Presenting } \\
\text { Symptom n (\%) }\end{array}$ & $\begin{array}{l}\text { Heartburn }=12(46.1 \%) \\
\text { Dysphagia }=14(53.9 \%)\end{array}$ & $\begin{array}{l}\text { Heartburn }=13(50 \%) \\
\text { Dysphagia }=13(50 \%)\end{array}$ & 0.78 \\
\hline $\begin{array}{l}\text { Mean BMI } \\
\left(\mathrm{kg} / \mathrm{m}^{2}\right)( \pm \mathrm{SD})\end{array}$ & $24.1 \pm 5.6$ & $28.1 \pm 5.1$ & 0.017 \\
\hline
\end{tabular}

\section{Endoscopy and 24-hour esophageal pH test results}

In the patient group, 18 (69.2\%) patients underwent endoscopic evaluation. Endoscopic findings indicated that the frequency of esophagitis was significantly higher in the patient group compared to the control group $(61.1 \%$ vs. $18.2 \%)(p=0.005)$. In the patient group, $54.5 \%$ of the patients had Los Angeles (LA) grade A and B esophagitis and $45.5 \%$ of them had LA grade $C$ and $D$ esophagitis. Moreover, no patient had peptic stricture and the frequency of hiatal hernia was almost significantly higher in the patient group compared to the control group. On endoscopy, only one patient was detected with $\mathrm{BE}$ and no significant difference was found between the two groups with regard to the frequency of LES incompetence $(p>0.05)$.

Only $10(38.5 \%)$ patients had 24-hour esophageal pH test results. Of these, $9(90 \%)$ patients were detected with reflux, including 6 (60\%) patients with distal reflux and 3 (30\%) patients with both distal and proximal reflux. In the control group, however, reflux was detected in $9(42.9 \%)$ out of 21 
patients, including $8(38.1 \%)$ patients with distal reflux and $1(4.8 \%)$ patient with both distal and proximal reflux. The frequency of pathological reflux was significantly higher in the patient group compared to the control group $(p=0.013)$. Table $\mathbf{2}$ and $\mathbf{3}$ present the endoscopic and 24-hour esophageal pH test results in both groups.

\begin{tabular}{lccc}
\hline Table 2. Endoscopic findings of patients. & $\begin{array}{c}\text { SS group } \\
(\mathbf{n = 1 8 )}\end{array}$ & $\begin{array}{c}\text { Control group } \\
(\mathbf{n = 2 2 )}\end{array}$ & $\mathbf{p}$ \\
\hline Esophagitis n (\%) & $11(61.1 \%)$ & $4(18.2 \%)$ & 0.005 \\
Peptic stricture $\mathrm{n}(\%)$ & - & - & - \\
Barrett's esophagus (\%) & $1(5.5 \%)$ & - & - \\
Hiatal hernia $\mathrm{n}(\%)$ & $6(33.3 \%)$ & $2(9.1 \%)$ & 0.57 \\
LES incompetence n (\%) & $7(38.9 \%)$ & $5(22.7 \%)$ & 0.31 \\
Gastric ulcer $\mathrm{n}(\%)$ & $0 \%$ & $2(9.1 \%)$ & 0.18 \\
Duodenal ulcer $\mathrm{n}(\%)$ & $0 \%$ & $2(9.1 \%)$ & 0.18 \\
\hline SS: Systemic Sclerosis & & & \\
\hline
\end{tabular}

Table 3. 24-hour esophageal pH test results of patients.

\begin{tabular}{lccc} 
& $\begin{array}{c}\text { SS group } \\
(\mathbf{n = 1 0 )}\end{array}$ & $\begin{array}{c}\text { Control group } \\
(\mathbf{n = 2 1 )}\end{array}$ & $\mathbf{p}$ \\
\hline Reflux & $9(90 \%)$ & $9(42.9 \%)$ & 0.013 \\
Distal reflux & $6(60 \%)$ & $8(38.1 \%)$ & \\
Distal + Proximal reflux & $3(30 \%)$ & $1(4.8 \%)$ & \\
\hline SS: Systemic Sclerosis & & & \\
\hline
\end{tabular}

\section{Esophageal manometry findings}

In manometric evaluation, the LES was situated at a mean distance of $43.6 \mathrm{~cm}$ in the patient group and $43.03 \mathrm{~cm}$ in the control group $(p>0.05)$. The mean esophageal body resting pressure in the patient group was $-0.73 \mathrm{mmHg}$ and was significantly lower than that of control group $(p<0.001)$. The mean resting LES pressure in the patient group was 3.3 $\mathrm{mmHg}$ and was significantly lower than that of control group $(p=0.028)$. Table 4 presents the esophageal manometry findings in both groups.

\begin{tabular}{|c|c|c|c|}
\hline & $\begin{array}{l}\text { SS group } \\
(n=26)\end{array}$ & $\begin{array}{c}\text { Control group } \\
(n=26)\end{array}$ & p \\
\hline $\begin{array}{l}\text { Resting LES pressure }(\mathrm{mm} / \mathrm{Hg}) \\
( \pm \mathrm{SD})\end{array}$ & $3.3 \pm 3$ & $20.3 \pm 4.94$ & $<0.001$ \\
\hline $\begin{array}{l}\text { Esophageal body resting } \\
\text { pressure }(\mathrm{mmHg})( \pm \mathrm{SD})\end{array}$ & $-0.73 \pm 2.4$ & $0.46 \pm 1.21$ & 0.028 \\
\hline LES distance $(\mathrm{cm})( \pm \mathrm{SD})$ & $43.6 \pm 3.6$ & $43.03 \pm 2.1$ & 0.43 \\
\hline
\end{tabular}

\section{DISCUSSION}

In the present study, GERD and complications were detected in most of the patients with SS. Moreover, a significant portion of the patients presented with both distal and proximal reflux. Given that all the patients were symptomatic, it is tempting to consider that reflux could be the primary cause of these complications.
Literature indicates that patients with SS have a higher frequency of GERD complications such as reflux esophagitis, esophageal stricture, and $\mathrm{BE}$ compared to the general population. ${ }^{[8]}$ Katzka et al. ${ }^{[9]}$ reported that patients with scleroderma are at increased risk of $\mathrm{BE}$ and esophageal adenocarcinoma. Wipff et a. ${ }^{[10]}$ also noted that patients with SS have an increased risk of esophageal adenocarcinoma and should be closely monitored. Lahcene et al. ${ }^{[11]}$ detected reflux esophagitis in 38\% and esophageal stricture and BE in 10\% of their patients. In our patients, although the frequency of reflux was higher compared to those reported in the literature and esophageal reflux was detected in $61 \%$ of the patients, no esophageal stricture was detected in any patient and BE was detected in only one patient.

Some previous studies found no significant association between esophageal symptoms and EMD. ${ }^{[12,13]}$ Another study reported that some patients presented no manometric signs of esophageal involvement despite presenting numerous esophageal symptoms and concluded that esophageal symptoms have low sensitivity, specificity, and predictive values in the diagnosis of SS. ${ }^{[14]}$ In contrast, Lahcene et al. ${ }^{[11]}$ reported that the frequency of esophageal symptoms was significantly higher in the presence of esophageal dysmotility and, therefore, these symptoms could be a simple warning sign necessitating prompt search of EMDs by manometry. [12] Similarly, in our study, all the patients with SS were symptomatic and were detected with EMD on manometry. It is commonly known that patients with SS mostly present to or are referred to gastroenterology polyclinics when their complaints of dysphagia and heartburn become symptomatic. Accordingly, in these patients, an assessment of esophageal involvement in the symptomatic period may allow early diagnosis and treatment of the patients and also prevent potential complications.

Patients with EMD are likely to experience numerous clinical problems such as early satiety, food regurgitation, progressive weight loss, malnutrition, and food impaction. ${ }^{[15]}$ Unintentional weight loss is the most sensitive indicator of malnutrition and should be monitored at regular intervals. Moreover, a low BMI $\left(<18.5 \mathrm{~kg} / \mathrm{m}^{2}\right)$ is an indicator of protein-energy malnutrition. ${ }^{[16]}$ In a 2009 study, Savarino et al. ${ }^{[17]}$ evaluated a total of 40 patients with SS including 35 women and 5 men and reported the mean $\mathrm{BMI}$ of the patients as $23 \mathrm{~kg} / \mathrm{m}^{2}$. Another study evaluated a group of patients with SS awaiting lung transplantation and reported that the mean BMI was $23.3 \mathrm{~kg} / \mathrm{m}^{2}$ and the men comprised $10 \%$ of the patients (18). In our study, the mean BMI in the patient group was $24.1 \mathrm{~kg} / \mathrm{m}^{2}$ and was significantly lower than that of control group. However, depending on the mean BMI in the patient group, it would be wise to assert that malnutrition could not be considered in our patients with SS. Additionally, the high frequency of reflux and other esophageal complications in such patients, as seen in our patients, could be the primary cause of food avoidance and the lower mean BMl compared to that of control subjects. Based on these findings, we suggest that an initial evaluation of esophageal involvement and nutrition 
status is essential for the assessment of malnutrition in patients with SS that present to the gastroenterology clinic after the onset of first symptoms.

Literature indicates that the normal range for the resting LES pressure in response to wet swallows on esophageal manometry is $16.6-35.4 \mathrm{mmHg}$. Additionally, the reported normal ranges for mean distal and proximal amplitude are 64-154 and 33-91 mmHg, respectively. ${ }^{[19]}$ The esophageal manometry findings of SS are associated with decreased esophageal motility with or without LES incompetence. Esophageal symptoms and manometric anomalies are commonly seen in patients with SS. ${ }^{[20]}$ In our study, the mean resting LES pressure and the mean esophageal body resting pressure in the patient group were $3.3 \mathrm{mmHg}$ and $-0.73 \mathrm{mmHg}$, respectively, and were significantly lower than those of control group. In all the patients with SS, the resting LES pressure was below $10 \mathrm{mmHg}$ and EMD was detected. In our study, manometric abnormalities were common in symptomatic patients, in accordance with the literature. Based on these findings, we consider that in patients with SS, a manometric evaluation of esophageal involvement followed by a 24hour esophageal $\mathrm{pH}$ test in the symptomatic period will be beneficial for the detection of GERD and its complications.

The association between gender and GI involvement in SS remains controversial in the literature. A previous study found a significant association between GI manifestations and gender in SS. ${ }^{[21]}$ In contrast, Abu-Shakra et al. ${ }^{[22]}$ found no significant relationship between $\mathrm{Gl}$ manifestations and demographic characteristics including gender, age at diagnosis, and disease type in patients with SS. However, a previous retrospective study that was conducted with 257 Greek patients with SS indicated that the frequency of GI involvement was higher in women than in men. ${ }^{[14]}$ Our study, unlike previous studies, had a female preponderance (96\%). This situation may be related to the fact that women in our society visit hospitals more than men. Taken together, all these findings implicate that SS mostly affects women and esophageal involvement may also lead to more frequent and serious complications in Turkish women.

Our study was limited in several ways. It had a retrospective design and had a small patient population since SS is a rare disease. However, no information was available in the study regarding the durations of the disease and the use of antacid-proton pump inhibitors and analgesic drugs by the patients.

\section{CONCLUSION}

Esophageal involvement is a hallmark manifestation of SS and typically occurs secondary to heartburn and dysphagia. SS commonly causes EMD and LES incompetence, thus precipitating patients towards reflux. Reflux also leads to EMD and as this vicious circle continues, the frequency of complications increases. In conclusion, GERD and GERDrelated complications have a high incidence in SS patients with esophageal symptoms in our society. It is important to refer these patients to experienced gastroenterology centers to be evaluated by endoscopic and other diagnostic methods.

\section{ETHICAL DECLARATIONS}

Ethics Committee Approval: This study was approved ethically by the local ethics committee (Date: 27.11.2019, Study No: 12) of from Ministry of Health Ankara City Hospital Clinical Research Ethics Committee, Ankara, Turkey.

Informed Consent: Because the study was designed retrospectively, no written informed consent form was obtained from patients.

Referee Evaluation Process: Externally peer-reviewed.

Conflict of Interest Statement: The author(s) declared no potential conflicts of interest with respect to the research, authorship, and/or publication of this article.

Financial Disclosure: The authors declared that this study has received no financial support.

Author Contributions: All of the authors declare that they have all participated in the design, execution, and analysis of the paper, and that they have approved the final version.

\section{REFERENCES}

1. Gilliland BC. Systemic sclerosis (scleroderma). In: Braunwald E, Fauci AS, Kasper DL, Hauser SL, Longo DL, Jameson JL, editors. Harrison's Principles of Internal Medicine, 15th ed. USA: McGraw-Hill Comp. Inc; 2001. p. $1937-$ 45.

2. Gyger G, Baron M. Systemic sclerosis gastrointestinal disease and its management. Rheum Dis Clin North Am 2015;41(3):459-73.

3. Bharadwaj S, Tandon P, Gohel T, et al. Gastrointestinal manifestations, malnutrition, and role of enteral and parenteral nutrition in patients with scleroderma. J Clin Gastroenterol 2015;49(7):559-64.

4. KatzPO, Gerson LB, Vela MF. Guidelines for the diagnosis and management of gastroesophageal reflux disease. Am J Gastroenterol 2013;108(3):30828.

5. Highland KB, Garin MC, Brown KK. The spectrum of scleroderma lung disease. Semin Respir Crit Care Med 2007;28(4):418-29.

6. Sarıyıldız MA, Batmaz I, Budulgan M, et al. Sistemik sklerozlu hastalarda depresif semptomlar: Klinik değişkenler, fonksiyonel durum ve yaşam kalitesi ile ilişkisi. Dicle Tıp Dergisi 2013;40(1):62-7.

7. Abozaid HSM, Imam HMK, Abdelaziz MM, El-Hammady DH, Fathi NA, Furst DE. High resolution manometry compared with the University of California, Los Angeles Scleroderma Clinical Trials Consortium GIT 2.0 in Systemic Sclerosis. Semin Arthritis Rheum 2017;47(3):403-8.

8. Marie I, P. Ducrotte, Denis P, Hellot MF, Levesque H. Oesophageal mucosal involvement in patients with systemic sclerosis receiving proton pump inhibitor therapy. Aliment Pharmacol Ther 2006;24(11-12):1593-601.

9. Katzka DA, Reynolds JC, Saul SH et al. Barrett's metapalasia and adenocarcinoma of the esophagus in scleroderma. Am J Med 1987;82(1):46-52.

10. Wipff J, Coriat R, Masciocchi M, et al. Outcomes of Barrett's oesophagus related to systemic sclerosis: a 3-year EULAR Scleroderma Trials and Research prospective follow-up study. Rheumatology (Oxford) 2011;50(8):1440-4.

11. Lahcene M, Oumnia N, Matougui N, Boudjella M, Tebaibia A, Touchene B. Esophageal Involvement in Scleroderma: Clinical, Endoscopic, and Manometric Features. ISRN Rheumatol 2011;2011:325826 
12. Poirier TJ, Rankin GB. Gastrointestinal manifestations of progressive systemic scleroderma based on a review of 364 cases. Am J Gastroenterol 1972;58(1):30-44.

13. Hostein J, Bost R, Carpentier P, Franco A, Fournet J. Motricit'e oesophagienne au cours de la maladie de Raynaud de la scl'erodermie et du syndrome de Raynaud pr'escl'erodermique. Gastroenterol Clin Biol 1985;9(2):130-5.

14. Lock G, Holstege A, Lang B, Schölmerich J. Gastrointestinal manifestations of progressive systemic sclerosis. Am J Gastroenterol 1997;92(5):763-71.

15. Ntoumazios SK, Voulgari PV, Potsis K, Koutis E, Tsifetaki N, Assimakopoulos DA. Esophageal involvement in scleroderma: gastroesophageal reflux, the common problem. Semin Arthritis Rheum 2006;36(3):173-81.

16. Baron $M$, Bernier $P$, Cote LF et al. Screening and therapy for malnutrition and related gastro-intestinal disorders in systemic sclerosis: recommendations of a North American expert panel. Clin Exp Rheumatol 2010;28(2 Suppl 58):42-6.

17. Savarino E, Bazzica M, Zentilin P et al. Gastroesophageal reflux and pulmonary fibrosis in scleroderma: a study using $\mathrm{pH}$-impedance monitoring. Am J Respir Crit Care Med 2009;179(5):408-13.

18. Fisichella PM, Reder NP, Gagermeier J, Kovacs EJ. Usefulness of $\mathrm{pH}$ monitoring in predicting the survival status of patients with scleroderma awaiting lung transplantation. J Surg Res 2014;189(2):232-7.

19. Ragunath K, Williams J G. A review of oesophageal manometry testing in a district general hospital. Postgrad Med J 2002;78(915):34-6.

20. Calderaro DC, Carvalho MAP, Moretzsohn LD. Esophageal manometry in 28 systemic sclerosis Brazilian patients: findings and correlations. Dis Esophagus 2009;22(8):700-4.

21. Simeon CP, Castro-Guardiola A, Fonollosa V et al. Systemic sclerosis in men: clinical and immunological differences. Br J Rheumatol 1996;35(9):910-1.

22. Abu-Shakra M, Guillemin F, Lee P. Gastrointestinal manifestations of systemic sclerosis. Semin Arthritis Rheum 1994;24(1):29-39. 